\title{
CONVERTION OF DSN-MUI'S FATWA ON ISLAMIC BANKING TO BE THE NATIONAL LAW: A Comparative Study in Muslim Countries
}

\author{
Angga Syahputra, Reni Ria Armayani \\ Institut Agama Islam Negeri Lhokseumawe, Indonesia \\ Email: anggasyahputra@iainlhokseumawe.ac.id
}

\section{Abstract}

Islamic banks in Indonesia have been significantly developing since 2008. This development has yet been supported by operational regulations. Islamic Banks operational mostly refers to fatwa of DSN-MUI. However, those fatwas must be converted to the regulations of Bank Indonesia or Financial Services Authority $(O J K)$ to have binding power. This article aims at describing DSN-MUI's fatwa position as the fundamental law of Islamic Banking implementation. Besides, this article compares the position of ulama's fatwa in implementing Islamic Bank in several Muslim countries. The article is originated from Doctrinal Legal research with conceptual and comparative approaches. The result shows that DSN-MUI;s fatwa position in implementing Islamic Banks is not yet operational because it must be first converted into the regulations of Bank Indonesia or OJK. Different condition found in other Muslim countries, ulama's fatwa becomes the main reference for implementing Islamic Banks. This is because the country places ulama's fatwa higher than banking authoritative.

Perbankan syariah di Indonesia terusmengalami kemajuan signifikan sejak tabun 2008. Perkembangan ini belum didukung dengan aturan-aturan yang bersifa operasional. Operasional perbankan syariah lebih banyak merujuk pada fatwa DSN-MUI. Namun, fatwa-fatwa tersebut harus dikonversi terlebih dahulukepada peraturan bank Indonesia atau Peraturan Otoritas Jasa Keuangan agar memiliki daya ikat. Artikel ini bertujuan mendeskripsikan kedudukan fatwa DSN-MUI sebagai dasar bukum pelasanaan perbankan syariah. Selain itu, artikel ini membandingkan kedudukan fatwa ulama dalam pelaksanaan perbankan syariah di beberapa negara muslim. Artikel ini berasal dari penelitian hukum doctrinal dengan pendekatan konsep dan komparatif. Hasil kajian artikel ini menunjukkan bahwa kedudukan fatwa DSNMUI dalam pelaksanaan perbankan syariah belum bersifat operasional. Karena 
Fatwa DSN-MUI harus dikonversi dalam bentuk Peraturan Bank Indonesia atau Peraturan Otoritas Jasa Keuangan. Kondisi berbeda ditemukan di negara-negara muslim, kedudukan fatwa ulama menjadi rujukan utama pelaksanaan perbankan syariah. Hal ini terjadi karena negara memposisikan fatwa ulama lebih tinggi dari otoritas perbankan.

Keywords: fatwa of DSN-MUI, Islamic Bank, Islamic Law.

\section{Introduction}

Sharia banks need clear legal basis to carry out their business activities. The existence of a sharia bank is actually intended to meet the needs of the Muslim community for the implementation of Islamic teachings as a whole including in the activities of delivering funds. ${ }^{1}$ Sharia banks in Indonesia have several legal bases, for example in Law Number 21 of 2008. In addition, Islamic banks also have other bases that are contained in Presidential Regulations, Bank Indonesia Regulations, and Ministerial Regulations.

The development of Islamic banks in Indonesia is caused by at least five things; the belief system of the Muslims, desire to institutionalize religious values that are adhered to as a majority population, prohibition of usury, good will from the government, and the success of Islamic countries in operating Islamic financial institutions, especially Islamic banks in their countries. ${ }^{2}$

As an Islamic product, Islamic banking requires a basic fatwa (other than the Al-Qur'an and Hadith) to carry out various activities in developing Islamic economic activities. Nowadays, the party given the authority to issue fatwas related to sharia economic activities in Indonesia is the National Sharia Board-the Indonesian Ulama Council (DSN-MUI). DSN is an institution formed by MUI in order to encourage the application of Islamic teachings in the field of Islamic economics/finance.

The formation of the DSN-MUI is a measure of efficiency and coordination of Ulama in responding to issues related to economic/financial issues. Various issues that require fatwa will be accommodated and discussed together in order to obtain a common view in their handling by each Sharia Supervisory Board (DPS) in Islamic financial institutions. ${ }^{3}$

1 Agus Waluyo, "Kepatuhan Bank Syariah Terhadap Fatwa Dewan Syariah Nasional Pasca Transformasi Ke Dalam Hukum Positif”, INFERENSI: Jurnal Penelitian Sosial Keagamaan, no. 2 (2016): 527, http:// dx.doi.org/10.18326/infsl3.v10i2.517-538.

2 Nur Hidayah, "Fatwa-fatwa Dewan Syariah Nasional Atas Aspek Hukum Islam Perbankan Syariah di Indonesia", Al-'Adalah, no. 1 (2011): 13-14.

3 Askar Abu Bakar, "Konsep Dasar Dewan Syariah Nasional (DSN)", Reasearchgate, accessed in April 1, 2020 https://www.researchgate.net/publication/334670686_KONSEP_DASAR_DEWAN_SYARIAH_ 
Even though it is considered good in general, some of the substances of Sharia Bank Act raise a problem related to sharia compliance. All aspects of sharia banking regulations, whether institutional, business activities, and liquidity management and financial instruments, actually boil down to one thing, that is sharia compliance, since the orientation of the three is how to apply sharia provisions in banking practices. The sharia provisions meant are Islamic law as stated by the DSN-MUI as far as it has been accommodated in the Legislation product. ${ }^{4}$

Sharia compliance in the Sharia Bank Law and its various implementing regulations raises problems, especially problems which related to the framework and the fatwa authority holder as its reference. On the one hand, it is stated that the business activities, products and services of sharia banks must comply with sharia principles (Islamic legal principles based on MUI fatwas). On the other hand it is stated that the MUI fatwa must be set in a Bank Indonesia Regulation (PBI)/Financial Services Authority Regulation (P-OJK). Although the two norms at first sight do not have a problem, in reality they are not. MUI as an institution holding fatwa authority raises problems related to its position as a private legal entity, while the necessity to include MUI fatwas in the $\mathrm{PBI} / \mathrm{P}-\mathrm{OJK}$ raises problems related to its consistency with the norms of appointing MUI as fatwa authority. For this reason, it is necessary to further discuss the position of DSN-MUI in Islamic banks so that the problem of overlapping authority can be solved, in this case we can compare with institutions of similar position in several countries such as Egypt, Brunei Darussalam, Sudan, Malaysia and Saudi Arabia.

\section{Research Methods}

The method used in this research is qualitative by using library research model. Primary data is obtained from existing laws and regulations, while secondary data is obtained from literature and existing scientific studies. In this study, data collection was carried out by examining/exploring several journals, books, and documents (both hard and soft files) and other sources deemed relevant to this research.

\section{The Position of Fatwa Institution}

The word position in the Indonesian Dictionary (KBBI) means level or dignity, or status regarding to the state or level of a person, institution or state, and so on. If it is connected to the objectives of this study, the position of the DSN-MUI

NASIONAL_DSN

4 Ja'far Baehaqi, "Paradoks Fatwa Dewan Syari’ah Nasional Majelis Ulama Indonesia Dalam Regulasi Hukum Perbankan Syari’ah Dan Alternatif Solusinya”, Al-Ahkam, no. 1 (2017): 3. 
means to determine the level or status of the state of the DSN-MUI Fatwa in the national legal system to implement sharia economics in Indonesia. Position can also be interpreted as how the influence of the DSN-MUI Fatwa in the national legal system and in encouraging the implementation of sharia economics.

The definition of a fatwa according to the Indonesian Dictionary (KBBI) is an answer in the form of a decision or opinion given by a mufti or expert about a problem, and/or advice from a pious person, good lessons, and advice. ${ }^{5}$ Fatwas are official answers to questions and problems concerning legal matters. Fatwa comes from the Arabic word al-ifta', al-fatwa which means giving decision. Fatwa is a form of legal explanation that has not been clearly stated, both in the Al-Qur'an and Hadith which are part of the construction of Islamic law. ${ }^{6}$

Etymologically, the word fatwa comes from Arabic, al-fatwa. According to Ibn Manzhur, quoted by Ma'ruf Amin, the word fatwa is a form of mashdar (verbal noun) of the word fata, that is fatwan, which means young, new, explanation, enlightenment. This opinion is almost the same as al-Fayumi, who states that alfatwa comes from the word al-fata, which means a strong young man. So that a person who issues a fatwa is said to be a mufti, because that person is believed to have the power to provide explanations (al-bayan) and answers to the problems he faces as the power possessed by a young man. ${ }^{7}$

The linguistic definition of a fatwa is an answer to an event (giving a firm answer to all events that occur in society). Fatwa according to the meaning of sharia is an explanation of sharia law in answering a case submitted by someone who asks, whether the explanation is clear or doubtful and the explanation leads to two interests; personal interest or public interest. ${ }^{8}$

Fatwa is an attempt by ulama to respond to problems faced by society that require legal decisions. The legal basis for the fatwa is Al-Qur'an, hadith and ijtibad. The tendency of reasoning carried out by scholars in answering a problem is closely related to ijtihad or legal opinion. As the word of Allah SWT. in the AlQur'an:" "... and we did not send before you, except for men whom we gave revelations

5 Kamus Besar Bahasa Indonesia, Ed. 3, Cetakan I, (Jakarta: Balai Pustaka, 2001), 314.

6 Umarwan Sutopo, "Dialektika Fatwa dan Hukum Positif di Indonesia: Meneguhkan Urgensi dan Posisi Fatwa di Masyarakat Muslim Nusantara”, Justicia Islamica, no. 1 (2018): 100.

7 Ma'ruf Amin, Fatwa Dalam Sistem Hukum Islam (Jakarta: Elsas, 2008), 19.

8 Rohadi Abdul Fatah, Analisis Fatwa Keagamaan Dalam Fikih Islam (Jakarta: Bumi Aksara, 2006), 7.

9 QS. An-Nahl [16]: 43 
to them; then ask those who have knowledge, if you don't know. "This verse is a rule about how someone is ordered to ask something if he/she do not know or if he/ she requires legal certainty to the expert. The word "ask" is the language of the Qur'an in explaining various problems. ${ }^{10}$

Fatwa is a legal stipulation on an issue determined by a competent ulama, both in terms of knowledge and prudence. Fatwa is an important legal instrument for Muslim communities in Indonesia in answering various problems since decolonization. ${ }^{11}$ Fatwas can be issued on the basis of request or not, therefore the development of fatwas in the Islamic legal system is very important, in line with social problems that are increasingly developing and complex when compared to the time of the Prophet and tabiin. Many of the problems that arise today did not occur during the time of the Prophet, on the other hand, Allah SWT has given two sources of law as guidance, Al-Qur'an and Hadith which are sufficient to solve the problem.

Fatwas do not have binding power, meaning that the requesting party does not have to follow the content or law of the fatwa which is given to him. However, fatwas tend to be dynamic because they are a response to new developments being faced and are responsive. There are several conditions that must be met in order to become a mufti or fatwa giver. Al-Nawawi, quoted by $\mathrm{M}$. Atho Mudzhar, states that these requirements are: mukallaf, Muslim, strong personality, trustworthy, pure from disgraceful characteristics, strong-spirited, intelligent minded, sharp minded, able to perform legal istinbath, physically and mentally healthy. Al-Nawawi added that to be able to be appointed as a mufti is not only monopolized by men, but women can also become mufti, as well as people with disabilities, such as blind or deaf as long as they understand the writing or signals conveyed to them in his position as mufti. ${ }^{12}$

Abu Umar Ibn al-Salah, as quoted by Al-Nawawi, states that there are two kinds of mufti, namely mufti mustaqil and mufti ghair mustaqil. A mustaqil mufti has the following requirements: First, knowing the legal arguments of the book, Sunnah, ijma, qiyas and things related to it. Second, knowing the conditions of

10 Ridwan Nurdin, "Kedudukan Fatwa MUI Dalam Pengembangan Ekonomi Syariah di Indonesia", a paper presented in discussion in June 17, 2011.

11 Wildan Imaduddin Muhammad, "Keberanjakan Fatwa Dari Legal Opinion Menjadi Legal Binding (Studi Kasus Fatwa DSN MUI Tentang Perbankan Syariah)", JURISPRUDENSI: Jurnal Imu Syariah, Perundang-undangan dan Ekonomi Islam, no. 2 (2019): 147, https://doi. org/10.32505/jurisprudensi. jurisprudensi.v11i2.1076.

12 M. Atho Mudzhar, Figh Sebagai Produk Pemikiran Hukum, dalam Membaca Gelombang Ijtihad Antara Tradisi dan Liberasi (Yogyakarta: Titian Ilahi Press, 1998), 91. 
dalil as well as its dilalah and how to take the law from it as explained in ushul fiqh. Third, knowing the knowledge of the Qur'an, Hadith, nasih and mansuh, nabwu, language, and tashrif as well as the differences of scholars within. Fourth, knowing figh, both ushuliyah and furuizyah issues.

A person having such qualification means can be categorized as al-mufti al-muthlaq al-mustaqil whose existence is fardhu kifayah. He is also called as al-mujtahid al-muthlaq al-mustaqil, because he do istinbath for law by himself without relying on certain scholars. In addition, a mufti mustaqil must know certain disciplines in accordance with the fatwa field..$^{13}$

MUI is a forum or assembly that brings together Indonesian Muslim scholars, zu'ama and intellectuals to unite the movements and steps of Indonesian Muslims in realizing common ideals. MUI was founded on 7 Rajab $1395 \mathrm{H}$, or July 26, 1975 in Jakarta, as a result of a meeting or deliberation of scholars and zuama who came from various parts of this country, including twenty-six ulama representing 26 Provinces in Indonesia, 10 ulama who became elements of the central level of Islamic organizations, such as NU, Muhammadiyah, Syarikat Islam, Perti, Al-Washliyah, Math'laul Anwar, GUPPI, PTDI, DMI and Al-Ittihadiyyah, 4 ulama from the Spiritual Islamic Service, Army, Air Force, Navy and POLRI as well as 13 figures/intellectuals who are individual figures. The deliberation resulted in an agreement to form a forum for deliberation of Muslim scholars, zu'ama and intellectuals, which was stated in a Charter for the Establishment of MUI, which was signed by all participants of the deliberation which was later called the National Ulama I Conference. ${ }^{14}$

The development of Islamic financial institutions in the country recently, as well as the existence of DPS in each financial institution, needs to establish DSNMUI which will accommodate various problems or cases that require fatwas in order to obtain equality in their handling in each of the existing DPS in Islamic financial institutions.

The plan to form DSN-MUI began to be discussed in 1990 during workshops and meetings that talked about bank interest and people's economic development, and recommended that the government facilitate the establishment of banks based on sharia principles. In 1997, MUI held a workshop for scholars on Sharia Mutual Funds, one of which was the establishment of the DSN. The meeting hold on October 14, 1997 was agreed to form the DSN-MUI. This proposal

13 Ma'ruf Amin, Fatwa Dalam Sistem Hukum Islam, 36.

14 Majelis Ulama Indonesia, "Profil MUI", accessed in April 1, 2020, https://.www.mui. or.id. 
was followed up so that the official DSN-MUI was compiled in $1998 .{ }^{15}$ MUI considers the DSN-MUI to be important to be formed to oversee all financial institutions, including Islamic banks. In addition, the DSN-MUI is intended to provide certainty and guarantee for Islamic law in Islamic economic issues ${ }^{16}$.

DSN-MUI is an institution formed by MUI which is structurally under MUI. DSN-MUI is an independent institution in issuing fatwas as a reference relating to economic, financial and banking issues. ${ }^{17}$ In principle, the formation of the DSN-MUI was intended as an effort for efficiency and coordination of ulama in responding to issues about economic and financial problems. In addition, it is expected that the DSN-MUI can act as a supervisor, director and impetus for the application of Islamic values and principles in economic life. Therefore, DSN-MUI plays a proactive role in responding to the development of Indonesian society in terms of economy and finance. ${ }^{18}$

One of the main tasks of the DSN-MUI institution is to explore, study and formulate the values and principles of Islamic law (sharia) in the form of fatwas to serve as a guide in economic activities and affairs in general and to the affairs and transaction activities of Islamic financial institutions in particular that is running the operations of Islamic financial institutions and supervising the implementation of fatwas. In order to carry out these main tasks, DSN-MUI has the authority to: ${ }^{19}(1)$ Issue a fatwa that binds DPS in each Islamic financial institution and becomes the basis for legal action of the related parties; (2) Issue a fatwa which forms the basis of provisions or regulations issued by authorized institutions, such as the Ministry of Finance and Bank Indonesia; (3) Provide support and or revoke and endorse names to be appointed as DPS in a sharia financial institution; (4) Inviting experts to explain a problem required in the discussion of sharia economics, including domestic and foreign monetary authorities or financial institutions; (5) Provide recommendations to Islamic financial institutions to stop deviations from fatwas issued by the DSN-MUI.

The current development of Islamic banking needs to be followed by effective supervisory measures to ensure that Islamic banking has grown and developed in a good manner, takes into account the principles of prudence, applies good corporate governance, has effective risk management, and complies with the sharia principles consistently. Therefore, Bank Indonesia, based on a risk

15 M. Cholil Nafis, Teori Hukum Ekonomi Syariah (Jakarta: UI Press, 2011), 82.

16 Zainuddin Ali, Hukum Perbankan Syariah (Jakarta: Sinar Grafika, 2010), 126.

17 Ascarya, Akad \& Produk bank Syariah (Jakarta: PT RajaGrafindo Persada, 2008 ), 206.

18 Zainuddin Ali, Hukum Perbankan Syariah, 126.

19 Zainuddin Ali, Hukum Perbankan Syariah, 89. 
oversight framework, has carried out on-site and off-site supervision with a focus on functional activities with high risk. ${ }^{20}$

In addition to the supervision of operational activities by Bank Indonesia as an external supervisor, things that are taken in order to prevent the operational activities of a sharia bank from escaping from sharia guidance are: (a) appointing bank leaders who have more or less control over muamalah figh; and (b) establishing DPS to supervise bank operations according to sharia. DPS, in this case, is a board that is intentionally formed to oversee the journey of Islamic banks so that they are always in accordance with sharia guidelines.

DPS has several roles; first, as an advisor and adviser to the board of directors, head of sharia business units, and heads of sharia branch offices on matters related to sharia aspects; second, as a mediator between the bank and the DSN-MUI in communicating proposals for the development of bank products and services that require studies and fatwas from DSN-MUI; third, as a representative of the DSNMUI assigned to the bank. DPS is required to explain the business activities and developments of the Islamic bank under supervision of DSN-MUI at least once a year. The position of DPS in Islamic banks is also as a guarantor who oversees the operation of the bank in accordance with sharia principles. ${ }^{21}$

Unlike DSN-MUI which is not regulated by law, DPS is regulated in the Law No. 10 of 1998 concerning Amendments to the Law No. 7 of 1992 concerning banking which accommodates DPS as a sharia supervisory institution for banks that apply sharia principles.

MUI is an institution that has authority in the religious field related to the interests of Indonesian Muslim. The DSN-MUI institution is an institution which has a strong authority in determining and maintaining the application of Sharia principles in operations at Sharia financial institutions. This is stated in the Law no. 21 of 2008 concerning Islamic Banking Article 32 and the Law No. 40 of 2007 concerning Limited Liability Companies, article 109, which in essence states that DPS must be formed in Sharia banks or companies that carry out business activities based on sharia principles. The DPS can only be appointed if it has received a recommendation from the DSN-MUI.22

20 Bank Indonesia, Outlook Perbankan Syariah Indonesia 2011 (Jakarta: Direktorat Perbankan Syariah, 2010), 30 .

21 M. Cholil Nafis, Teori Hukum Ekonomi Syariah, 98.

22 Bambang Iswanto, "Peran Bank Indonesia, Dewan Syariah Nasional, Badan Wakaf Indonesia dan Baznas dalam Pengembangan Produk Hukum Ekonomi Islam di Indonesia", Iqtishadia, no. 2 (2016): 430, http://dx.doi.org/10.21043/iqtishadia.v9i2. 
DPS is a sharia supervisory agency in charge of overseeing the operations and practices of Sharia Financial Institutions (LKS) in order to remain consistent and adhere to sharia principles. The DSN-MUI Basic Guidelines (Chapter II paragraph 5) states that DPS is an agency that exists in Islamic financial institutions and is tasked to overseeing the implementation of DSN-MUI decisions in Islamic financial institutions. Meanwhile, the DSN-MUI Bylaw Guidelines (Article 3 Paragraph 8) emphasize that to make the role of DSN more effective in Islamic financial institutions a Sharia Supervisory Board, abbreviated as DPS, is formed as the DSN representative at the relevant Sharia financial institution. DPS, as regulated in PBI No. 6/24/PBI/2004 is a board that supervises sharia principles in LKS business activities.

In the DSN-MUI Fundamental Guidelines, the working mechanism of DPS is explained as follows: first, periodically supervising Islamic financial institutions under its supervision; second, it is obliged to submit a proposal for the development of a sharia financial institution to the leadership of the institution concerned and to the DSN-MUI; third, reporting the development of products and operations of the sharia financial institutions that is supervised by DSN-MUI at least twice in one fiscal year; fourth, formulating problems that require discussion of the DSN-MUI.

The duties and functions of DPS are regulated in the DSN-MUI Bylaw Guidelines as follows: First, DPS in each financial institution has the main duties: (a) to provide suggestion and advice to directors, heads of sharia business units and heads of branch offices of Islamic financial institutions relating to sharia aspects; (b) perform supervision, both actively and passively, especially in implementing the DSN-MUI fatwa and providing direction/supervision for products/services and business activities to comply with sharia principles; (c) as a mediator between Islamic financial institutions and DSN-MUI in communicating proposals and suggestions for product and service development from Islamic financial institutions that require studies and fatwas from DSN-MUI. Second, the DPS functions as a representative of DSN-MUI which is placed in a sharia financial institution and is obliged to: (a) follow the DSN-MUI fatwa; (b) formulating problems that require the endorsement of the DSN-MUI; (c) report to DSN-MUI the business activities and developments of the Islamic financial institutions that is supervised at least once a year.

The formation of the DSN-MUI is a measure of efficiency and coordination of the ulama in responding to issues related to economic/financial issues. DSNMUI is expected to encourage the application of Islamic teachings in economic 
life. DSN-MUI plays a proactive role in responding to the dynamic development of Indonesian society in terms of economy and finance. ${ }^{23}$

DSN-MUI focuses on developing the application of sharia values in economic activities in general and finance in particular, issuing fatwa related to financial activities, issuing fatwa on sharia financial products and services, and supervising the application of fatwa that have been issued.

The authority of DSN-MUI is to issue fatwa that binds the DPS in each Islamic financial institution and becomes the basis for legal action of the parties concerned, issues fatwa that becomes the basis for the provisions/regulations issued by the competent institution, such as the Ministry of Finance and Bank Indonesia, providing recommendations and/or revoke the recommendation of names who will be DPS in a sharia financial institution, inviting experts to explain a problem that is needed in the discussion of sharia economics, including domestic and foreign monetary authorities/financial institutions, giving warnings to Islamic financial institutions to stop deviations from the fatwa issued by the DSN-MUI, propose to the competent institution to take action if the warning is not obeyed. ${ }^{24}$

DSN-MUI, according to the provisions of Article 1 Paragraph (9) of the Bank Indonesia Regulation, is a board established by MUI which is assigned and has the authority to stipulate fatwa regarding products and services in bank business activities that carry out business activities based on sharia principles. ${ }^{25}$

The authority of fatwa on sharia economy in Indonesia is under DSN-MUI. The plenary members consist of sharia experts and economists or finance experts with Islamic insight. In discussing a problem to be issued a fatwa, DSN-MUI involves partner institutions such as the Financial Accounting Standards Board (DSAK), the Indonesian Institute of Accountants (IAI) and the Department of Sharia Economics and Finance (DEKS) of Bank Indonesia.

Fatwa of the National Sharia Council has the following powers: (1) Compliance with fatwa of DSN-MUI is the basic requirement in the production and development of new products and activities to be issued by banks; (2) Sharia banking operations must refer to Islamic law, so that every product and service available in Islamic banking is based on the DSN-MUI Fatwa; (3) One of the primary differences between sharia and conventional banking is its implementation; sharia banking must comply with Islamic law, in this case fatwa of the DSN-MUI; (4) Law No.

23 Majelis Ulama Indonesia, “Tentang Dewan Syariah Nasional”, accessed in April 1, 2020, https://www.mui.or.id.

24 Majelis Ulama Indonesia, "Tentang Dewan Syariah Nasional”, accessed in April 1, 2020, https://www.mui.or.id.

25 Cik Basir, Sengketa Perbankan Syariah (Jakarta: Kencana Prenada Media Grup, 2005), 60. 
21 of 2008 concerning on Sharia Banking requires the DSN-MUI Fatwa as one of the legal bases that must be obeyed; (5) Operationally sharia business cannot be implemented by a sharia bank without referring to the principles written in the DSN-MUI Fatwa; (6) Sharia banking business activities must comply with the sharia principles issued by MUI; (7) New products and services must adhere to the Fatwa of the DSN-MUI; (8) all sharia businesses can be implemented in principle if it is in accordance with the Fatwa of the DSN-MUI; (9) The bank will continue to operate the product by conducting audiences with Bank Indonesia on licensing and plans for implementing that new product.

DSN-MUI fatwa has several obstacles in its application, such as: (1) The paradigm of customers who are not familiar with sharia banking products and operations; (2) Regulations are not in line with fatwas, such as IMBT products, if it is implemented in accordance with fatwas, then the object of IMBT must be in the name of the bank, therefore it will result in high costs such as tax regulations; (3) Different perception between DSN-MUI and Bank Indonesia about Islamic economic fatwas; (4) There is a DSN-MUI fatwa that is not too detailed so that for technical matters it is sometimes debatable; (5) Technical constraint, in the form of information systems (IT), for example the profit share mechanism for the third parties which should fluctuate every month (depending on bank profits). For now, it is still constrained by the fix set-up every month; (6) Socialization obstacle. The DSN-MUI fatwa uses Arabic terms (especially contract type) and PBI also uses the same term, so it takes time for banks to disseminate information to third parties (society) on banking products that use Arabic terms. In addition, the lack of budget for marketing and promotion also becomes an obstacle for Islamic banking to be increasingly recognized by the society; (7) Business Constraints. Several DSN-MUI fatwas are irrelevant based on business perspective. This is because LKS will not make a product that is less profitable and cannot be absorbed by third parties; (8) Government support Constraint. Government policies become an obstacle to the implementation of the DSN-MUI Fatwa by LKS. For example, the double tax that has been applied in Murabahah contract (bank must buy the goods first then sold to the customers).

\section{The Position of National Sharia Board}

Fatwas place an important position in Islamic law since fatwas are opinion from Islamic jurists (fuqaha) regarding the legal standing of new problem arising in the society. When a new problem which has no explicit legal provision arises, either in the Qur'an, Sunnah and ijma' or previous juristic opinions, then fatwa 
is one of the normative institutions that is competent to answer or determine the legal standing of the problem. ${ }^{26}$ Furthermore, fatwas also legitimize new socioeconomic practices that do not explicitly exist in the two authoritative sources of religion (Al- Qur'an and Sunnah) (Black and Hosen, 2009: 412). Therefore, scholars or mufti will explore the values contained in the Al-Qur'an and Sunnah to solve these problems. ${ }^{27}$

DSN-MUI plays an important role, that is the duty and authority to issue fatwas that becomes the basis operational for every Islamic financial institution, in this case, Islamic banking in Indonesia. ${ }^{28}$ There are several countries that put fatwas or fatwa-making institutions in the legal system and government structures like Brunei Darussalam, Malaysia and Saudi Arabia. Meanwhile, there are those who put fatwas out of the legal system and government structures like Egypt and Indonesia. This results in different positions and legal strengths of fatwas for each country. Fatwa or fatwa institutions that are in the legal system or government structure have more binding legal position and power than those outside the legal system and government. ${ }^{29}$

Referring to several countries today, the fatwa's function can be divided into three. First, the state that makes sharia as the basis and state laws that is implemented thoroughly and perfectly, so fatwas have very significant role. Second, the state that applies secular law, in this system fatwas do not have any role and function. Third, a state that combines the first and second system (Islamic law and secular law), so the function of fatwas rests on the scope of Islamic law only. Indonesia is a country that applies the third model, therefore it makes fatwa studies more interesting. ${ }^{30}$

MUI's authority in issuing fatwas is a function of MUI as stated in Article 4 of MUI's Articles of Association (AD/ART), entitled MUI functions: First, as a forum for deliberation by Muslim scholars, zuama and intellectuals in protecting people and having Islamic good life. Second, as a gathering place

26 Muhamad Ibnu Afrelian \& Imahda Khoiri Furqon. "Legalitas Dan Otoritas Fatwa Dewan Syariah Nasional Majelis Ulama Indonesia Dalam Operasional Lembaga Keuangan Syariah”, MIZANI: Wacana Hukum, Ekonomi dan Keagamaan, no. 1 (2019): 6, DOI: 10.29300/mzn. v6i1.2195.

27 Niki Alma Febriana Fauzi, "Fatwa Di Indonesia: Perubahan Sosial, Perkembangan, dan Keberagaman", Jurnal Hukum NOVELTY, no. 1 (2017): 110.

28 Aflah Sihombing, "Kredibilitas Dewan Syariah Nasional dalam Sistem Pengawasan Pada

Perbankan Syariah", HIJRI - Jurnal Manajemen Pendidikan dan Keislaman, no. 2 (2017): 85.

29 Isa Ansori, "Kedudukan Fatwa Di Beberapa Negara Muslim (Malaysia, Brunei Darussalam dan Mesir)", Analisis, no. 1 (2017): 140, https://doi.org/10.24042/ajsk.v17i1.1790.

30 M. Cholil Nafis, Teori Hukum Ekonomi Syariah, 3. 
for Muslim scholars, zu'ama and intellectuals to develop and practice Islamic teachings and have Islamic ukhuwah. Third, as a forum that represents Muslims in interfaith relations and consultation. Fourth, as a fatwa giver to Muslims and the government, whether it is requested or not. ${ }^{31}$ DSN-MUI issues fatwa related to a product, service, and provisions after obtaining a fatwa request from the monetary authority or LKS. ${ }^{32}$

Referring to the Law No. 12 of 2011, DSN-MUI fatwa does not have binding legal force. Based on Article 7 paragraph (1) of the Law Number 12 of 2011, the types and hierarchies of the Laws and Regulations are: the 1945 Constitution of the Republic of Indonesia, Decrees of the People's Consultative Assembly, Government Regulations in Lieu of Laws, Government Regulations, Presidential Regulations, Provincial Regulations and Regency/City Regulations.

On the other hand, in making Bank Indonesia Regulations related to Sharia Banks in Indonesia, Bank Indonesia may only refer to the DSN-MUI fatwa as the basis for arranging PBI and may not refer to other fatwas issued by institutions other than DSN-MUI, this is stated in the Law Number 21 of 2008 and strengthened by the Decree of the Board of Directors of Bank Indonesia Number 32/34/1999 in article 31.

The fatwa issued by DSN-MUI is not positive law $^{33}$, same as MUI fatwas in other fields. Former Chief Justice of the Constitutional Court (MK) Mohammad Mahfud MD has stated that fatwas are religious opinion, not positive law. According to Mahfud, positive law is everything that is in the law and regulated by state institutions, while MUI is not a state institution. ${ }^{34}$ On the one hand, MUI fatwa is non-binding and there is no legal compulsion for the society to comply with the fatwa's provisions. On the other hand, through certain patterns, the content of MUI fatwa can be absorbed and transformed into material content of legislation that has legal force and is generally binding. ${ }^{35}$

31 Slamet Suhartono, "Eksistensi Fatwa Majelis Ulama Indonesia Dalam Perspektif Negara Hukum Pancasila", al-Ihkam, no. 2 (2017): 450, DOI: 10.19105/al-ihkam.v12i2.1255.

32 Tuti Hasanah, "Transformasi Fatwa Dewan Syariah Nasional ke dalam Hukum Positif”, SYARLAH Jurnal Hukum dan Pemikiran, no. 2 (2016): 165, DOI: 10.18592/sy.v16i2.1022.

33 Zubairi Hasan, Undang-undang Perbankan Syariab: Titik. Temu Hukum Islam dan Hukum Nasional , ed.1 (Jakarta: Rajawali Pers, 2009), 25.

34 B. Doni, "Mahfud MD: "Apakah Fatwa MUI Harus Diikuti? Tentu Tidak", Detik News, January 17, 2017, accessed in April 8, 2020,

https://news.detik.com/berita/d-3397842/mahfud-md-apakah-fatwa-mui-harus-diikutitentu-tidak

35 Diana Mutia Habibaty, "Peranan Fatwa Dewan Syariah Nasional-Majelis Ulama Indonesia terhadap Hukum Positif Indonesia”, Jurnal Legislasi Indonesia, no. 4 (2017): 448 
In order for the fatwas issued by the DSN-MUI to be valid and binding as positive law in Indonesia, the Law No.21 of 2008 concerning Islamic Banking states that the fatwas issued by the DSN can be followed up as PBI. ${ }^{36}$

Since January 1,2014, in the context of sharia banking regulations, there have been changes after the transfer of banking regulatory and supervisory authority from Bank Indonesia to the Financial Services Authority (OJK). Previously, the form of banking regulation was Bank Indonesia Regulation (PBI), then after that transition it changed into OJK Regulation. However, if the OJK has not issued a new regulation, then all PBI are still binding and must be regarded as OJK Regulations. ${ }^{37}$

The issuing of the Law Number 21 of 2008 concerning Islamic Banking, based on the perspective of Islamic law, is part of the law enforcement process (tasyri ${ }^{\prime}$. By being passed as part of the product of legislation, Islamic law which was originally only binding on the basis of religious beliefs for Muslims became state law that was binding not only based on religious beliefs, but on all citizens with the support of the state officials.

Same as Islamic law in general, DSN-MUI fatwa is an unwritten law eventhough it is a written form in a unique format. As unwritten law, the DSN-MUI fatwa only applies internally. This means that people's obedience to him is based on his religious belief since the DSN-MUI fatwa is part of Islamic law. We can see the position of the DSN-MUI fatwa in the national legal framework by looking at the position of the MUI in the institutional framework in the government. This is because the binding power of a legal product issued by an institution will be influenced by the position of the institution in governance. ${ }^{38}$

On the one hand, the DSN-MUI is given the mandate to issue fatwas which become the basis for the operations of Islamic banks. In this case the DSN-MUI fatwa has a binding power like statutory regulations even though it is not a state institution. On the other hand, the DSN-MUI fatwa must be set in the form of $\mathrm{PBI} / \mathrm{P}-\mathrm{OJK}$ which means the binding strength of the DSN-MUI fatwa occurs when it is stated in the PBI/P-OJK. This imbalance leads to cause problems in the future, both from the perspective of the DSN-MUI as an institution, sharia banking businessmen, as well as the quality of the resulting regulations.

36 Imam Abdul Hadi, "Kedudukan dan Wewenang Lembaga Fatwa (DSN-MUI) pada Bank Syariah", Economic: Jurnal Ekonomi dan Hukum Islam, no. 2 (2011): 4.

37 Jafar Baehaqi, Paradoks Fatwa Dewan Syariah Nasional..., 2.

38 Tuti Hasanah, "Transformasi Fatwa Dewan Syariah Nasional ke dalam Hukum Positif ", SYARIAH Jurnal Hukum dan Pemikiran, no. 2 (2016): 169. 
By the end, the fatwa issued by the DSN-MUI did not have a significant role for Islamic banks which had an impact on the development of Islamic banking products and services. This is because the fatwa becomes only as a complement to the products and services of Islamic banks. Another thing is because the DSN-MUI fatwa is just a law requirement for the Islamic banking sector in the context of sharia compliance. Another fact that shows the DSN-MUI fatwa as a complementary is that the fatwa is issued after the products and services have been published, not with a prior discussion mechanism. ${ }^{39}$

\section{Comparison to Other Countries}

Several Islamic countries have mufti institution that is in charge of issuing fatwas. Indonesia does not have that kind of institution. Indonesia only has DSN-MUI, so if there are differences in fatwas, it is not a problem or it can be questioned. On the other hand, if there is a mufti institution, it can actually create rigidity because the fatwa issued must be strictly followed.

MUI is not a fatwa institution like in other Islamic countries because the authority is not official. "MUI is not a government institution. Nevertheless, the fatwas issued by the ulama have been able to give it life and included in legislation products, such as legal products or banking legislation," said Atho. ${ }^{40}$

The MUI fatwa that is included in the law is not because it is forced, but because it is considered appropriate. "That is the value of a non-government institution such as MUI, being independent," said Atho.

The Egyptian fatwa institute is the first fatwa institution established in the Islamic world. This institution was founded in 1895 based on a decree from Khedive Egypt Abbas Hilmi addressed to Nidzarah Haqqaniyah No. 10 dated November 21, 1895. The letter was received by the concerned person, Nidzarah, on 7 Jumad al-Akhir 1313 number 55.

The Egyptian fatwa institute is one of the pillars of Islamic institutions in Egypt besides al-Azhar ash-Sharif, al-Azhar University and the Ministry of Waqf. The Egyptian fatwa institute was one of the institutions under the Ministry of Justice. The Grand Mufti of Egypt is always asked for his opinion on the death sentence and so on. However, the duties and roles of the Egyptian fatwa institute are not limited there, even their reach is not only Egypt but also throughout the

39 Eja Armaz Hardi, "Fatwa DSN MUI dan Perkembangan Produk Perbankan Syariah Di

Indonesia", An nisbah: Jurnal Ekonomi Syariah, no. 2 (2018): 1, http://doi.org/10.21274/ an.2019.5.2.

40 ANTARA, "Fatwa dan Kedudukannya dalam Islam", accessed in April 6, 2020

http://www.antarasultra.com/print/266339/ fatwa-dan-kedudukannya-dalam-islam. 
world. This can be seen by the many questions that were sent to the Egyptian fatwa institute where the questioners came from various parts of the world, completed with the fatwa training for foreign students. Encouraged by this factor, regarding to the position of the Egyptian fatwa institution which is always used as a reference (marjiiah) because of its moderate method (tawasuth), Daar al-Ifta has always kept up with the latest technological developments in order to be able to realize these demands.

Egypt has officially had Daar al-Ifta (office that issues fatwas) since 1895 which is headed by the country's grand mufti. Theoretically, the mufti must be separated from the state in order to avoid bias and irregularities in issuing fatwas. However, the reality shows the role of the state in creating legal authority is enormous. The state has an interest in this role, whether from a religious, social or political perspective.

Skovgaard-Petersen stated that from $19^{\text {th }}$ century, mufti was appointed by the president to be public servant and called Mufti al-Diyar al-Misriyyah (Mufti of Egypt), then the term was changed into Mufti al-Jumburiyyah (Mufti of the Republic) (Skovgaard \& Petersen, 1997).$^{41}$ Globally, the duties of this institution are divided into two; religion and courts. As for religious duties, it has several points including accepting requests and questions for fatwa and answering them in various languages, determining the beginning of Islamic months, holding fatwa training for foreign students, issuing official statements regarding to religious issues, compiling scientific research, answering misunderstanding of Islam and establishing a distance learning system.

Then the court duties of the Egyptian fatwa institution is in the form of giving decisions according to syara' on the death sentence against the accused. In this case, the Egyptian Grand Mufti checked all existing files (evidences from beginning to end) and looked for proof in religion and opinions of the scholars regarding the case which would later be returned to the judiciary in the final verdict.

The Egyptian fatwa institute continues to improve its performance, this can be seen from its sections. The Egyptian fatwa institute consists of five sections under its auspices; a fatwa board section, Islamic research center, fatwa training center, translation center, communication center and electronic fatwa and other supporting sections. Apart from the above sections, the Egyptian fatwa institute also has a special team, including a special maqashid syariah team and a team for monitoring and disseminating scientific data.

41 Jacob Skovgaard \& Petersen, Defining Islam for the Egyptian State: Muftis and Fatwas of the Dar al-Ifta' (Leiden: Brill, 1997), 101-103. 
The rapid development of technology where every institution is required to continue to follow it, the Egyptian fatwa institute has begun to expand its mission and vision. Various methods and media are taken through the website (which can be seen at www.dar-alifta.org, facebook, twitter or youtube), magazines, monthly newsletters, classic fatwa treasures (encyclopedia containing all fatwas from the first mufti to the latest one, even all this fatwa will be computerized).

Fatwa and its institution are a necessity for the Muslim society. People always ask the experts about religious law for guidance in their daily life. This situation is found in all countries with Muslim populations, whether in the minority or the majority Muslim. Fatwa institutions are found in countries with an Islamic constitution, or without an Islamic constitution, and even in secular countries. This institution is not only needed by the society, but also by the executive in making policies, by the legislative body for the formation of laws, and by the judiciary to administer cases, both civil and criminal.

Brunai Darussalam, a country that implements Islamic law, since November 7, 1994 by order of Sultan Hassanal Bolkiah, the Mufti Department of the Kingdom is no longer under the Ministry of Hal Ehwal Ugama, but has become a separate department under the Prime Minister. The Mufti of the Kingdom is directly responsible to Duli the Excellency regarding to his duties as the Mufti of the Kingdom. ${ }^{42}$ By placing mufti under the Prime Minister, the position and status of fatwa is getting stronger. The mission of the Mufti of the Kingdom is as an institution that issues fatwas and irshad (guidance), and becomes an institution that collects, issues and disseminates Islamic knowledge. ${ }^{43}$

At the regional level in Europe and North America, fatwa institutions are also established. European Council for Fatwas and Research is a fatwa institution at for European council in Dublin. This institution is established in London, March 30 1997, its members are well-known ulama from European States and Islam countries. The head of this institution is Syaikh Yusuf al-Qardhawi. Meanwhile, the Figh Council of North America is a fatwa institution established in 1980. The origin of this institution came from Religious Committee from The Muslim Students Association of US and Canada in 1986. After that, ISNA was established, The Religious Committee became the Figh Council of North America.

42 Haji Japar bin Haji Mat Dain, Institusi Fatwa: Peranan dan Sumbangan Jabatan Mufti Kerajaan Negara Brunei Darussalam, P. 116, quoted from Buku Kementerian Hal Ehwal Ugama Brunei, published by Pusat Dakwah Islamiah, P. 12.

43 Haji Japar bin Haji Mat Dain, Institusi Fatwa: Peranan dan Sumbangan Jabatan Mufti Kerajaan Negara Brunei Darussalam, 116-117. 
This institution consists of well-known scholars in North America and several Muslim countries.

The Organization of Islamic Conference as an organization of Muslim countries in Jeddah also has a fatwa institution. The Islamic World League (Rabithah al-Alam al-Islami), an international organization initiated by Saudi Arabia, also has a fatwa institution. There have been attempts from Egypt to unite fatwa institutions and mufti positions from all over the world in a world organization, but this has not been successful.

Some circles do not acknowledge MUI fatwa because of its unclear status from the point of view of state institutions. A former president even asked MUI to be dissolved because it was not an official state institution and thus the president and ministers did not have to listen to his fatwa.

It is different from Sudan. Sudan places the Sharia Supervisory Board in the structure of the central bank (Bank of Sudan). The position of Sharia Supervisory Board is at the same level as the deputy governor. All fatwas issued by the Sharia Supervisory Board can be applied directly in Islamic banks, because the Sharia Supervisory Board's fatwa is a decision of the central bank. Fatwa of Sharia Supervisory Board can be positivated by the central bank.

The Sharia Supervisory Board functions to issue fatwas related to sharia compliance. The Sharia Supervisory Board also functions as a breaker for differences of opinion or interpretation of sharia principles. In addition to the Sharia Supervisory Board (a kind of DSN-MUI), Sudan requires Islamic banks to have a DPS of at least three people.

In Malaysia, an institution like DSN-MUI is part of the structure of Bank Negara Malaysia which is at the same level as the department, namely under the Islamic Banking and Takaful Department. This position is lower than that of the DSN in Sudan, which is at the same level as the deputy. Fatwas issued by DSN Malaysia are automatically recognized by the central bank and binding on Islamic banks. Mufti is authorized to change, or cancel any fatwas previously issued by him or the former mufti. Every fatwa which has been reported will bind everyone in the country concerned, and bind all the Sharia Courts in the country concerned.

In Islamic legal literature, fatwa or ifta' is defined as an explanation of a legal decision without binding effect. In fact, according to the provisions of the Malaysian legal system, it can be defined as a statement issued by the Mufti (head of the fatwa committee) which is published, confirmed and known by the public 
through the media. ${ }^{44}$

From the history of the establishment of Islamic banks in Malaysia, it was started by the establishment of Bank Islam Malaysia Berhad (BIMB) which was founded in 1983. BIMB was also accompanied by the establishment of the Shariah Supervisory Council (SSC) whose task was to supervise BIMB's operations from deviating from the provisions of Islamic law. ${ }^{45}$

As the Islamic banking system developed in Malaysia, SSC was also asked to supervising conventional banks offering sharia banking services in early 1993. As with the development of Islamic banking in Malaysia, the Malaysian government established the highest Islamic authority in Malaysia, namely the National Shariah Advisory Council (NSAC) which was established on May 1, 1997, this institution functions as the highest authority in deciding sharia issues in Islamic financial institutions for both banks and non-banks. NSAC is in the organizational structure of Bank Negara Malaysia (BNM). NSAC members are appointed by the board of directors.

BNM has three years working period, and it can be re-elected at the next term. The objectives of the establishment of the NSAC are to: (1) Being the only authority that provides advice to Bank Negara Malaysia regarding banking operations and sharia insurance; (2) Coordinating sharia issues concerning on sharia finance and banking, as well as Islamic insurance; and (3) Analyzing and evaluating sharia aspects of new schemes or products proposed by banking institutions and takaful companies.

By establishing National Shariah Advisory Council, the duty of the Shariah Supervisory Council (SSC) in Islamic financial institutions is only to supervise the operations of the financial institutions under their supervision whether they comply with the applicable regulations or not.

The key to Malaysia's success in encouraging the development of the Islamic economy lies in its very strong policy support, as well as a continuing public education process. In general, the master plan for the advancement of the Malaysian financial sector and capital market can be divided into three main stages. First, development of financial infrastructure. Second, increasing the capacity and capability of financial institutions. Third, development of regulations that support a healthy competitive situation. Evidence of this partiality is manifested by the government by placing funds in existing Islamic banks. According to official data

44 Muhammad Majdy Amiruddin, "Imposisi Fatwa Terhadap Regulasi Perbankan Syariah (Studi Komparasi Perbankan Syariah Indonesia dan Malaysia)", Bilancia, no. 1 (2018): 69.

45 Karnaen A. Perwataatmadja dan Hendri Tanjung, Bank Syariah Teori, Praktik, dan Peranannya (Jakarta: Celestial Publishing, 2007), 196. 
released by the Malaysian Ministry of Finance, 53\% of Malaysia's state budget funds are placed in Islamic banks. In addition, the placement of Malaysian BUMN funds in the neighboring country's Islamic banks. ${ }^{46}$

In Saudi Arabia, the High Council for Fatwa and Sharia Supervisor was established to issue a national-level fatwa which becomes a reference for DPS and Islamic banks as a whole. Saudi Arabia has mufti which are gathered in al-Lajnah al-Da'imah li al-Bubus al-'Ilmiyyah wa al-Ifta' appointed by the state. The fatwas issued are required to follow the schools adhered to by Saudi Arabia, it must also refer to the kingdom's policy and political stability. ${ }^{47}$ This fatwa board becomes the determinant and decision maker for fatwa or fatwas among DPS in Islamic banks.

DPS members are chosen from groups who have extensive knowledge of religion, and deepen Islamic fiqh, muamalat figh, Islamic economics, and understand the prevailing laws and regulations related to Islamic banks. At the Faisal Islamic Bank and At-Takwa Islamic Bank, the determination is made by the general meeting of shareholders. The meeting has the right to determine who will be a member of DPS and what conditions must be met by prospective members of DPS

The At-Takwa Islamic Bank Regulation grants additional authority to DPS, that is in the condition that DPS rejects the board of directors because of its suggestions, DPS can invite an extraordinary GMS and convey bank fraud on sharia principles. The GMS can take the right steps to disseminate DPS views and statements through media information. ${ }^{48}$

\section{Conclusion}

The development of Islamic banking in Indonesia requires strong support from the government in terms of the legal and institutional basis of the DSNMUI. The government needs to re-examine the position of the DSN-MUI in issuing a fatwa so it can be implemented without having to be issued in a Bank Indonesia Regulation or OJK Regulation. The government can take an example of the position of similar institutions in various countries in determining fatwas to be implemented in national Islamic bank. The position of fatwa institutions in

46 Sofyan Al-Hakim, "Perkembangan Regulasi Perbankan Syariah Di Indonesia”, Ijtihad, Jurnal Wacana Hukum Islam dan Kemanusiaan, no. 1 (2013): 30.

47 Rusli, “Tipologi Fatwa di Era Modern: Dari Offline ke Online”, Hunafa: Jurnal Studia Islamika, no. 2 (2011): 281.

48 Hasanuddin, "Peran Dewan Syariah Nasional", accessed in April 6, 2020

http://www.pa-kendal.go.id/beranda-mainmenu-1-1/artikel/artikel/peran-dewan-syariahnasional, 
various countries is much stronger and more binding than the DSN-MUI, due to the strong support from the government. Fatwa institutions in various countries do not need other rules in their implementation, in contrast to the DSN-MUI which requires other rules in the implementation of the issued fatwas. The government needs to provide support by giving more authority to the DSN-MUI in order to develop a strong and advanced national Islamic banking system, as stated by Umar Chapra, in order to realize an Islamic banking system, the positive role of the state is an absolute matter. ${ }^{49}$

\section{References}

Afrelian, Muhamad Ibnu \& Furqon, Imahda Khoiri. "Legalitas Dan Otoritas Fatwa Dewan Syariah Nasional Majelis Ulama Indonesia Dalam Operasional Lembaga Keuangan

Ali, Zainuddin. Hukum Perbankan Syariah. Jakarta: Sinar Grafika, 2010.

Al-Hakim, Sofyan. "Perkembangan Regulasi Perbankan Syariah Di Indonesia", Ijtihad, Jurnal Wacana Hukum Islam dan Kemanusiaan, no. 1 (2013): 30.

Amin, Ma’ruf. Fatwa Dalam Sistem Hukum Islam. Jakarta: Elsas, 2008.

Amiruddin, Muhammad Majdy. "Imposisi Fatwa Terhadap Regulasi Perbankan Syariah (Studi Komparasi Perbankan Syariah Indonesia Dan Malaysia)". Bilancia, no. 1 (2018): 69.

ANTARA. "Fatwa dan Kedudukannya dalam Islam", accessed in April 6, 2020 http:// www.antarasultra.com/print/266339/fatwa-dan-kedudukannya-dalamislam

Ansori, Isa. "Kedudukan Fatwa Di Beberapa Negara Muslim (Malaysia, Brunei Darussalam dan Mesir)". Analisis, no. 1 (2017): 140, https://doi.org/10.24042/ ajsk.v17i1.1790.

Ascarya. Akad \& Produk bank Syariah. Jakarta: PT RajaGrafindo Persada, 2008.

Baehaqi, Ja'far. "Paradoks Fatwa Dewan Syari'ah Nasional Majelis Ulama Indonesia Dalam Regulasi Hukum Perbankan Syariah dan AlternatifSolusinya”. Al-Ahkam, no. 1 (2017): 3 .

49 M. Umer Chapra, Sistem Moneter Islam, terj. Ikbwan Abidin (Jakarta: Gema Insani Press, 2000), 15. 
Bakar, Askar Abu. "Konsep Dasar Dewan Syariah Nasional (DSN)", Reasearchgate, accessed in April 1,2020, https://www.researchgate.net/publication/334670686_ KONSEP_DASAR_DEWAN_SYARIAH_NASIONAL_DSN

Bank Indonesia, Outlook Perbankan Syariah Indonesia 2011. Jakarta: Direktorat Perbankan Syariah, 2010.

Basir, Cik. Sengketa Perbankan Syariah. Jakarta: Kencana Prenada Media Grup, 2005.

Chapra, M. Umer. Sistem Moneter Islam, terj. Ikhwan Abidin. Jakarta: Gema Insani Press, 2000.

Doni, B. "Mahfud MD: “Apakah Fatwa MUI Harus Diikuti? Tentu Tidak", Detik News, 17 Januari 2017, accessed in April 8, 2020, https://news.detik.com/ berita/ d-3397842/mahfud-md-apakah-fatwa-mui-harus-diikuti-tentu-tidak

Fatah, Rohadi Abdul. Analisis Fatwa Keagamaan Dalam Fikih Islam. Jakarta: Bumi Aksara, 2006.

Fauzi, Niki Alma Febriana. "Fatwa Di Indonesia: Perubahan Sosial, Perkembangan, dan Keberagaman”. Jurnal Hukum NOVELTY, no. 1 (2017): 110.

Habibaty, Diana Mutia. "Peranan Fatwa Dewan Syariah Nasional - Majelis Ulama Indonesia terhadap Hukum Positif Indonesia”. Jurnal Legislasi Indonesia, no. 4 (2017): 448 .

Hadi, Imam Abdul. "Kedudukan dan Wewenang Lembaga Fatwa (DSN-MUI) Pada Bank Syariah”, Economic: Jurnal Ekonomi dan Hukum Islam, no. 2 (2011): 4.

Hardi, Eja Armaz. "Fatwa DSN MUI dan Perkembangan Produk Perbankan Syariah Di Indonesia”. An nisbah: Jurnal Ekonomi Syariah, no. 2 (2018): 1, http:// doi.org/10.21274/an.2019.5.2.

Hasan, Zubairi. Undang-Undang Perbankan Syariah: Titik Temu Hukum Islam dan Hukum Nasional, ed.1. Jakarta: Rajawali Pers, 2009.

Hasanah, Tuti. "Transformasi Fatwa Dewan Syariah Nasional Ke Dalam Hukum Positif”, SYARIAH Jurnal Hukum dan Pemikiran, no. 2 (2016): 165, DOI: 10.18592/sy.v16i2.1022

Hasanuddin. "Peran Dewan Syariah Nasional", accessed in April 62020 http://www. pa-kendal.go.id/beranda-mainmenu-1-1/artikel/artikel/peran-dewan-syariah- 
nasional

Hidayah, Nur. "Fatwa-fatwa Dewan Syariah Nasional Atas Aspek Hukum Islam Perbankan Syariah di Indonesia”. Al-Adalah, no. 1 (2011): 13-14.

Iswanto, Bambang. "Peran Bank Indonesia, Dewan Syariah Nasional, Badan Wakaf Indonesia dan Baznas dalam Pengembangan Produk Hukum Ekonomi Islam di Indonesia”.Iqtishadia, no. 2(2016): 430, http://dx.doi.org/10.21043/ iqtishadia.v9i2

Japar, Haji bin Haji Mat Dain. Institusi Fatwa: Peranan dan Sumbangan Jabatan Mufti Kerajaan Negara Brunei Darussalam, mengutip Buku Kementerian Hal Ehwal Ugama Brunei, terbitan Pusat Dakwah Islamiah.

JURISPRUDENSI: Jurnal Ilmu Syariah, Perundang-undangan dan Ekonomi Islam, no. 2 (2019): 147, https://doi.org/ 10.32505/jurisprudensi.jurisprudensi. v11i2.1076.

Kamus Besar Bahasa Indonesia, edisi ke 3, cetakan I. Jakarta: Balai Pustaka, 2001.

Majelis Ulama Indonesia. "Profil MUI”, accessed in April 1, 2020, https://.www. mui.or.id.

Majelis Ulama Indonesia. “Tentang Dewan Syariah Nasional”, accessed in April 1, 2020, https://www.mui.or.id.

Mudzhar, M. Atho. Figh Sebagai ProdukPemikiran Hukum, dalam Membaca Gelombang Ijtihad Antara Tradisi dan Liberasi . Yogyakarta: Titian Ilahi Press, 1998.

Muhammad, Wildan Imaduddin. "Keberanjakan Fatwa Dari Legal Opinion Menjadi Legal Binding (Studi Kasus Fatwa DSN MUI Tentang Perbankan Syariah)".

Nafis, M. Cholil. Teori Hukum Ekonomi Syariah. Jakarta: UI Press, 2011.

Perwataatmadja, Karnaen A \& Tanjung, Hendri. Bank Syariah Teori, Praktik, dan Peranannya. Jakarta: Celestial Publishing, 2007.

Rusli. “Tipologi Fatwa di Era Modern: Dari Offline ke Online”. Hunafa: Jurnal Studia Islamika, no. 2 (2011): 281.

Sihombing, Aflah. "Kredibilitas Dewan Syariah Nasional dalam Sistem Pengawasan Pada Perbankan Syariah”. HIJRI - Jurnal Manajemen Pendidikan dan 
Keislaman, no. 2 (2017): 85.

Skovgaard, Jacob \& Petersen. Defining Islam for the Egyptian State: Muftis and Fatwas of the Dar al-Ifta.' Leiden: Brill, 1997.

Suhartono, Slamet. "Eksistensi Fatwa Majelis Ulama Indonesia Dalam Perspektif Negara Hukum Pancasila”. al-Ihkam, no. 2 (2017): 450, DOI: 10.19105/ al-ihkam.v12i2.1255

Sutopo, Umarwan. "Dialektika Fatwa Dan Hukum PositifDi Indonesia: Meneguhkan Urgensi Dan Posisi Fatwa Di Masyarakat Muslim Nusantara”. Justicia Islamica, no. 1 (2018): 100.

Syariah". MIZANI: Wacana Hukum, Ekonomi dan Keagamaan, no. 1 (2019): 6, DOI: $10.29300 /$ mzn.v6i1.2195

Waluyo, Agus. "Kepatuhan Bank Syariah Terhadap Fatwa Dewan Syariah Nasional Pasca Transformasi Ke Dalam Hukum Positif". INFERENSI: Jurnal Penelitian Sosial Keagamaan, no. 2 (2016): 527, http://dx.doi.org/10.18326/infsl3. v10i2.517-538 